\title{
Miecz z zamku w Szczytnie
}

The Sword from Szczytno Castle

\begin{abstract}
Abstrakt: Artykuł omawia miecz przechowywany w Muzeum Mazurskim w Szczytnie, który pochodzi z dawnych zbiorów Prussia Museum. Zabytek zachował się w dość dobrym stanie ogólnym - brak jedynie sztychowej partii głowni. Głownia mieczowa zachowała się na długości $615 \mathrm{~mm}$, przy całkowitej długości oręża $855 \mathrm{~mm}$. Charakterystyczny jest jelec, w rzucie z góry o esowatym kształcie, a głowica ma postać odwróconej gruszki. Na podstawie cech konstrukcyjnych
\end{abstract}

miecz ze Szczytna należy określić jako egzemplarz późnośredniowieczny z głownią typu XVIIIa według R.E. Oakeshotta, jelcem Iza oraz głowicą Ts. Analogiczne zachowane okazy, jak i przedstawienia ikonograficzne dowodzą, że tego rodzaju miecze były najbardziej popularne w drugiej połowie $\mathrm{XV}$ oraz początkach - pierwszej ćwierci XVI stulecia. O okolicznościach pozyskania tego egzemplarza mamy bardzo lakoniczne informacje - był on znaleziony w ruinach zamku.

Słowa kluczowe: miecz, Szczytno, zamek, średniowiecze, zakon krzyżacki

Wśród średniowiecznej broni białej siecznej i kolnej największą estymą wśród polskich badaczy cieszy się zdecydowanie miecz. Wynika to zapewne nie tylko z jego wiodącej roli w średniowiecznym uzbrojeniu, ale również dużego znaczenia w ówczesnej symbolice, jak i jurysdykcji (np. Ławrynowicz 2005; Marek 2017). Stąd też nie powinno dziwić, że tej kategorii uzbrojenia zaczepnego poświęcono w polskiej literaturze bronioznawczej najwięcej miejsca (np. Głosek 1973; Głosek, Nadolski 1978; Głosek 1984; Marek 2004; Żabiński i in. 2014). Zauważony przy okazji tych studiów niedostatek znalezisk mieczy, które można datować od drugiej ćwierci XV w. po schyłek tegoż stulecia, próbowano wielorako tłumaczyć. Z jednej strony zmniejszającym się zapotrzebowaniem na miecze wobec upowszechniających się innych rodzajów białej broni siecznej, z drugiej - coraz rzadziej toczonymi w Królestwie Polskim wielkimi konfliktami zbrojnymi, które z centrum państwa wyraźnie przesunęły się ku jego wschodnim granicom, na pogranicze Wielkiego Księstwa Litewskiego (por. np. Głosek, Nadolski 1978: 27-28; Nadolski 1984: 67-69; Głosek 1990: II2). Dziś wydaje się jednak, że zauważony wcześniej fakt był po prostu odzwierciedleniem stanu badań - aż do schyłku lat 80 . XX w. zainteresowania naukowe archeologów z rzadka tylko wykraczały poza granicę XV w. Wraz ze zmianą tej perspektywy, i poszerzeniem zainteresowań także o obiekty ze schyłku średniowiecza i młodsze, wyraźnie zaczęła wzrastać również baza zasobów 


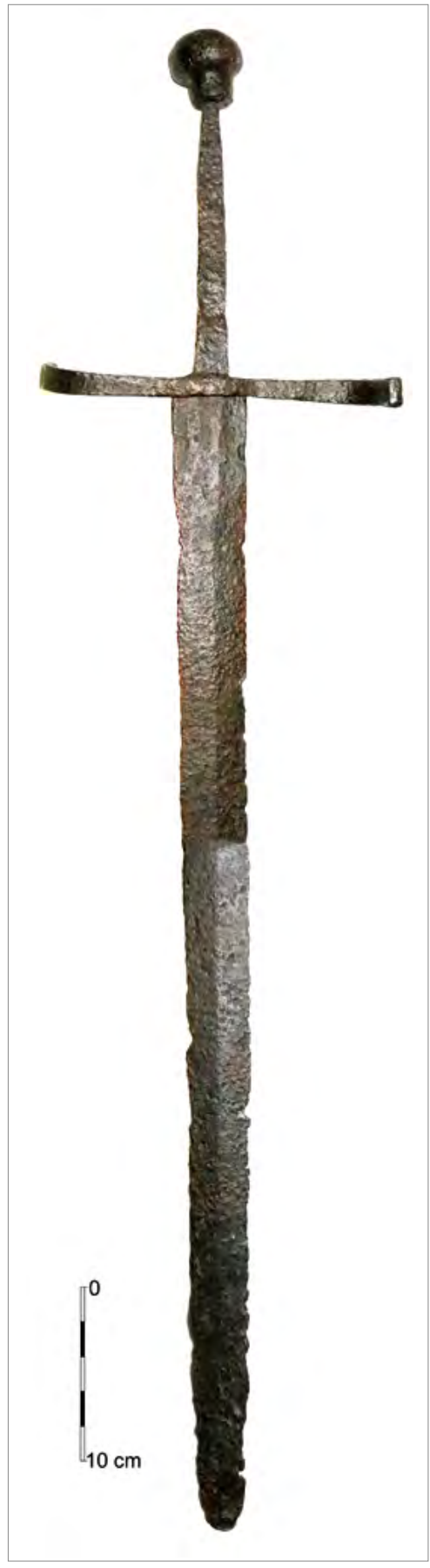

Ryc.1. Miecz ze Szczytna - widok ogólny.

Fot. P. Strzyż.

uzbrojenia wczesnonowożytnego (np. Augustyniak 1988; 1992: 78-80, ryc. 73-74, 82-84, 88; 1996: 213, ryc. 7). Także dokładniejsze przyjrzenie się muzealnym magazynom zaowocowało opublikowaniem wielu bardzo interesujących okazów dawnej broni (np. Adamiak, Zdaniewicz 20I5).

Do tej grupy zabytków można zaliczyć również miecz, który jest przechowywany w Muzeum Mazurskim w Szczytnie (nr inw. MMA-30/920/72). Pochodzi on jeszcze z przedwojennych zbiorów Prussia Museum, ale jak dotąd nie był szerzej omawiany w literaturze przedmiotu. Informacje o jego proweniencji są szczątkowe. Wiadomo jedynie, że znaleziono go na terenie miejscowego zamku. Zachował się w dość dobrym stanie ogólnym. Wprawdzie nosi wyraźne ślady zalegania w ziemi, lecz ubytki wywołane przez korozję nie są duże. Brakuje jedynie sztychowej partii głowni, a w miejscu odłamania sztychu jest ona na krótkim odcinku zgięta (ryc. I). Głownia jest dość smukła i zachowała się na długości 6I5 mm, przy całkowitej długości oręża $855 \mathrm{~mm}$. Jej szerokość u nasady wynosi $43 \mathrm{~mm}$. Ma przy tym przekrój spłaszczonego rombu, o grubości $6 \mathrm{~mm}$. Na krótkim odcinku zastawy zaopatrzono jąw zbrocze długości około 6o-70 mm i szerokości $13 \mathrm{~mm}$. Charakterystyczny jest jelec, w rzucie z góry o esowatym kształcie. Ma on długość $195 \mathrm{~mm}$. Wykonano go ze sztabki żelaznej o zmiennym przekroju - przy głowni ma on przekrój spłaszczonego jednostronnie pięciokąta $(7 \times$ I2 $\mathrm{mm})$, a na końcach przybiera postać wyodrębnionych prostopadłościanów $(7 \times 16 \mathrm{~mm})$. Szerokość otworu na trzpień, który wykonano w jelcu, wynosi 


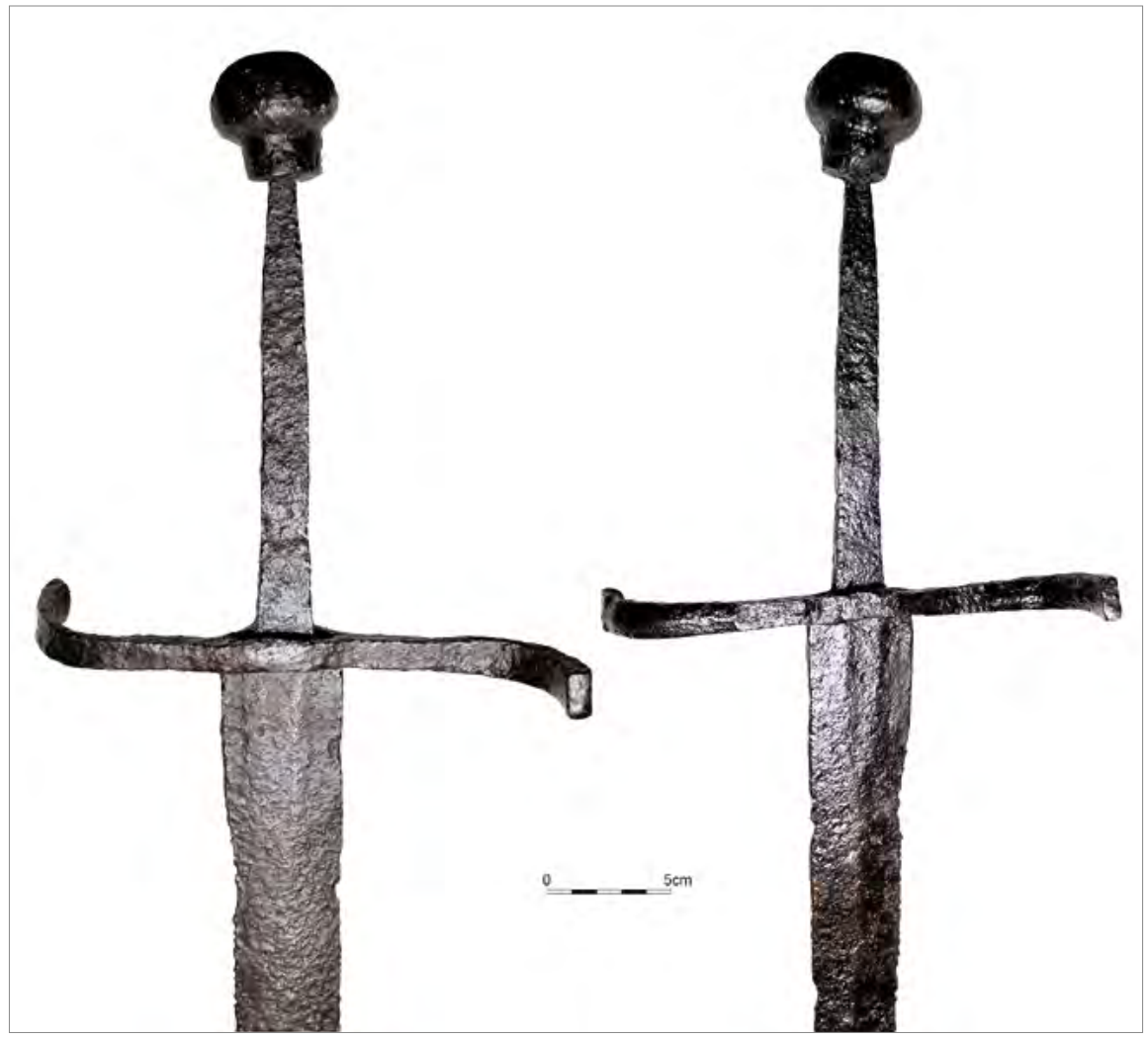

Ryc. 2. Miecz ze Szczytna - rękojeść, strona lewa i prawa. Fot. K. Skóra.

$36 \mathrm{~mm}$. Trzpień rękojeści ma szerokość $20 \mathrm{~mm}$ przy głowni do $10 \mathrm{~mm}$ przy głowicy, a jego grubość waha się od $6 \mathrm{do} 4 \mathrm{~mm}$. Lekko uszkodzona głowica ma postać odwróconej gruszki. Jej dolna średnica wynosi 26-28 mm, zaś górna $43 \mathrm{~mm}$ (ryc. 2: I-2). Waga tak zachowanej całości (po konserwacji) to 950 g. Zarówno na głowni mieczowej, jak i na trzpieniu nie zaobserwowano występowania znaków mieczniczych i kowalskich.

Przechodząc do klasyfikacji poszczególnych elementów składowych miecza ze Szczytna, wypada klasycznie zacząć od głowni. Jej rękojesśc ma jednoręczny chwyt, a charakterystyczny romboidalny przek rój i bardzo krótkie zbrocze pozwalają włączyć ją w poczet typu XviıIa według R.E. Oakeshotta (1997). Największe rozpowszechnienie tego rodzaju brzeszczotów przypada na XV stulecie (Oakeshott 1997: 69-70, Fig. 36A, 43B). Podobną pozycję chronologiczną mają tego typu formy, które A. Bruhn Hoffmeyer umieściła w grupie IVc, charakteryzującej się ośmiokątnym przekrojem głowni, o rękojeści zarówno jedno-, jak i dwuręcznej (Bruhn Hoffmeyer 1954: I39-I40, pl. XXXIV-XXXV). 
Z kolei ,gruszkowata" głowica jest okrągła w przekroju, a jej podstawa jest wyraźnie wyodrębniona. Pozwala to na sklasyfikowanie jej jako wariant $\mathrm{Ts}$, bowiem forma $\mathrm{T}_{3}$ charakteryzuje się raczej łagodniejszym przejściem. Ten typ głowic jest dość często spotykany w mieczach z drugiej połowy XV stulecia; na zachodzie Europy pojawia się wcześniej, już w pierwszej ćwierci XV w. (Oakeshott 1997: 106, Fig. 8I-82). Jelec o esowatym w rzucie bocznym kształcie mieści się w stylu I2 (Oakeshott 1997: II8: Fig. 4I, 43D).Z czasem jednak wyróżniono kilka dalszych jego odmian. Tym samym formy o lekko esowatym wygięciu znalazły się w typie I2a, te zaś bardziej wygięte W I2b (Aleksić 2007: 3I-32, IOI, Fig. 4). Jest to forma ochrony dłoni charakterystyczna dla XV i początku XVI w. Tego rodzaju esowate jelce znalazły zastosowanie także w konstrukcji rękojeści rapierów i zostały zaklasyfikowane jako typ 2 według Normana, występujący (w różnych wariantach) od schyłku średniowiecza aż do około 1650 r. (Norman 1980: 64-66).

Klasyfikacja głowni mieczowych charakteryzujących się romboidalnym przekrojem głowni nie jest zadaniem prostym, gdyż o tym podziale decydują nierzadko detale konstrukcji, które czasami, z uwagi na zły stan zachowania zabytków, trudno jest dostrzec. Z tego względu wskazanie odpowiednich dla zabytku ze Szczytna analogii nie jest też sprawą łatwą. Jak się wydaje, jedynym dobrym odpowiednikiem z terenu państwa zakonu krzyżackiego w Prusach jest miecz o głowni zaopatrzonej w krótkie zbrocze (typ XVIIIa), z jelcem stylu 6 i głowicy typu H.Jest on obecnie przechowywany w zbiorach Muzeum Historyczno-Archeologicznego w Elblągu, lecz, niestety, nie ma dokładnie określonego miejsca znalezienia. Został on wydatowany na drugą połowę XIV - XV w., o czym przesądziły przede wszystkim cechy rękojeści (Marek 2014: 62-63, I55, nr kat. 132, ryc. 26:a-d; Kwiatkowski 2016:34I-342, 344, ryc. II.38:a).

$\mathrm{Z}$ ziem polskich z pewnością do ważniejszych odpowiedników należy miecz z grobowca Kazimierza Jagiellończyka, pozyskany podczas prac remontowych prowadzonych w Kaplicy Świętokrzyskiej w katedrze na Wawelu w 1974 r., a obecnie przechowywany w katedralnym skarbcu. Jest on zachowany w bardzo złym stanie (prawie całkowity brak głowni). Rękojeść została zaopatrzona w wyraźnie esowaty jelec oraz głowicę wariantu $\mathrm{T}_{3}$, $\mathrm{z}$ tym że została ona wykonana ze stopu miedzi. A. Nadolski oraz M. Głosek klasyfikowali jego głownię jako typ Xvırb. Na jego datowaniu zaważył oczywiście rok śmierci króla, w związku z tym przyjmuje się, że oręż został wykonany przed I 492 r., ale po roku I 454, czyli roku zawarcia małżeństwa z Elżbietą Rakuszanką (np. Głosek i in. 1978: 36, nr kat. 81, tabl. 23; Kozłowski 1978: 463, 47I-472, ryc. 16-17; Głosek 1984: 158, nr kat. 265; Nadolski 1984: 68, ryc. 27; Głosek 1998: 23, 26, ryc. I). Mniej znanym jest natomiast fakt, że podobny miecz - ale nieco lepiej zachowany - został znaleziony w latach $30 . \mathrm{XX}$ w. w grobie jednego z synów Kazimierza Jagiellończyka, a mianowicie Aleksandra, który zmarł w I506 r. Został on pochowany w Wilnie, w tamtejszej katedrze (Wilkus i99i: 538, 547, ryc. 16; Biborski i in. 2004: 199, przypis I2). 
Z istotniejszych nowszych odkryć, dobrze zachowany miecz ze zbliżonym do omawianego wariantem głowni i jelca pochodzi z siedziby rycerskiej w Nowym Mieście nad Wartą, stan. 2. Został on znaleziony po II(?) wojnie przez okolicznych mieszkańców - był wbity pionowo w kopiec, z którego po osunięciu się nasypu wystawała głowica z rękojeścią. Obecnie jest on przechowywany w $\mathrm{Mu}$ zeum Regionalnym w Jarocinie. Jego długość całkowita wynosi $\mathrm{II} 8 \mathrm{~cm}$, z czego około $90 \mathrm{~cm}$ przypada na głownię. Jest ona romboidalna w przekroju, o szerokości $3,5 \mathrm{~cm}$ u nasady. Identyczny jak w przypadku miecza ze Szczytna jest esowaty w rzucie górnym jelec w stylu $12 b$ według R.E. Oakeshotta. Miecz ten jest datowany na około połowę XV w. (Grygiel, Jurek 1996: 165, ryc. 13I).

W 1996 r. podobny do okazu ze Szczytna miecz odkryto także w grobie nr 4 w trakcie badań klasztoru mniszek dominikańskich w Raciborzu, pow. loco. Zaliczono go do typu XVII, wskazując jednak na znaczne podobieństwo także do typu XVıIIb. Rękojeść zaopatrzono w głowicę wariantu Ts oraz esowaty jelec, sklasyfikowany jako styl I2. Chronologię tego egzemplarza określono na lata I350-I450, z zastrzeżeniem jednak, że prawdopodobnie około I500 r. głownia mogła zostać poddana ponownej oprawie zgodnie z wymogami panującej wówczas mody (Biborski i in. 2004: 190 i nn., tabl. I, fig. I-5; por. także Marek 2008: 83, Fig. II5:a).

Pozostałe miecze z obecnych ziem polskich o elementach rękojeści tożsamych z egzemplarzem ze Szczytna są datowane na drugą połowę XV i początek XVI w. Należą do nich okazy m.in. z Uszyc koło Częstochowy (typ XVIa, $T_{3}, 9$ pochodna) oraz nielokalizowany egzemplarz z prywatnej kolekcji w Wielkopolsce (typ xv Ia, $\mathrm{T}_{3}$, I3) (Głosek 1984: 164, nr kat. 330; 1998: 23). Głowica typu Ts pochodząca najpewniej z Płocka jest też przechowywana w Płockim Muzeum Diecezjalnym (Pudło 2010: 5I, 99, nr kat. V:57). Z kolei okaz miecza o głowni w typie XVII z głowicą $\mathrm{H}_{2}$ oraz esowatym (dość zniszczonym) jelcem znany jest Golubia-Dobrzynia, gdzie wyłowiony został z Drwęcy. Jest on datowany na pierwszą połowę XV w. (Majewski 2018: 4I-42, tab. I:2, ryc. 5:2).

Z Republiki Czeskiej wszystkie miecze zaopatrzone w esowaty jelec typu I2b są datowane na drugą połowę XV stulecia. Należą do nich takie okazy jak np. Brniště-Velký Grunov, okr. Česká Lípa, Přelouč, okr. Pardubice oraz okaz z Muzeum w Prahaticach. Współwystępują one z głowniami typu XVIa, XIIIa oraz XVIIIb. Głowice są zwykle dyskoidalnego kształtu (typ H) (Hošek i in. 2019: 71, 228, 364-365, nr kat. 13, 204, 397). Cztery inne miecze zostały wyposażone w głowice Ts, przy czym dwie z nich wystąpily w połączeniu z jelcem stylu I2a - zabytki z muzeów w Broumovie i Nymburku. Te dwa okazy są datowane na schyłek XV - początek XVI w. (Hošek i in. 2019: 287, 326-327, nr kat. 285, 34I, Pl. XXI). Wreszcie głownie w typie XVIIIa również w głównej mierze są datowane na drugą połowę XV w. Można wskazać na dobrze datowany egzemplarz z Mstěnic, okr. 


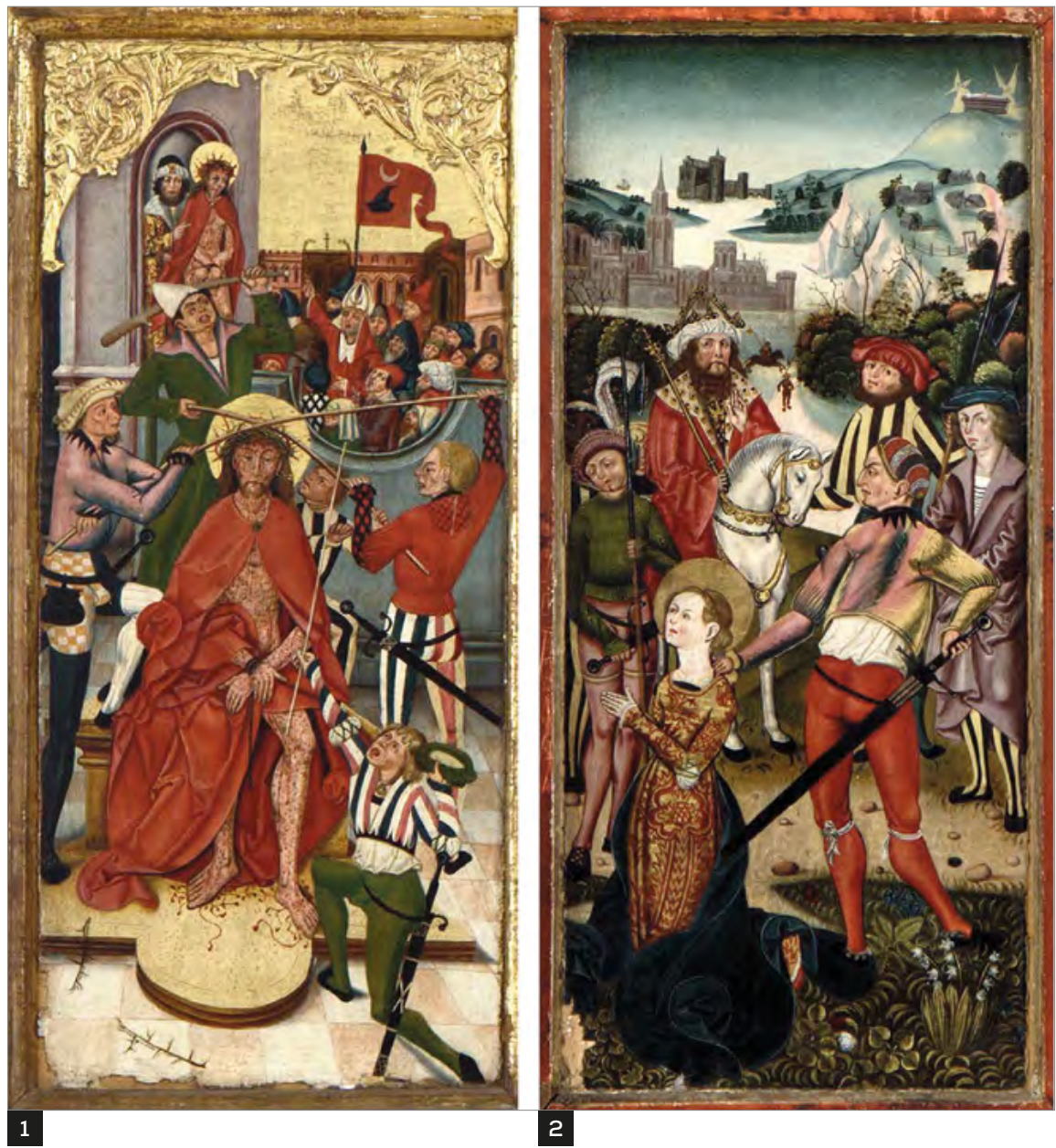

Ryc.3. Miecze o wąskiej głowni i rękojeści z esowatym jelcem. Pentaptyk z kościoła szpitalnego pw. Ducha Świętego w Bartoszycach, ok. I510-1520:

I - scena Cierniem ukoronowanie;

2 - scena Ścięcie św. Barbary (wg Kwiatkowski 20I6: ryc. II.4O, II.4I).

Třebíč pochodzący sprzed i 468 r. (Krajíc i in. 1997: 250-251, ryc. I-7; Hošek i in. 20I9: I80-I8I, nr kat. I46) czy datowany szerzej, bo na XV w., okaz z Morawskiego Krumlowa, okr. Znojmo (Žakovský 20ıı: 130-I32, I68, ryc. ı:2, Tabl. I; Hošek i in. 2019: 178-179, nr kat. I43).

$\mathrm{Z}$ terenu Słowacji znane są m.in. dwa miecze, przechowywane w zbiorach Spiskiego Muzeum w Lewoczy, których głownie typu Xvia oraz Xx zostały wyposażone $\mathrm{w}$ głowice $\mathrm{T}_{3}$. Ich datowanie obejmuje XV i XVI w., przy czym bardzo prawdopodobne jest, że część z nich to starsze wyroby, które zostały poddane 
powtórnej oprawie około I500 r. Są to bardzo dobrze zachowane egzemplarze, które pochodzą zapewne z dawniejszych kolekcji muzealnych lub zbiorów kolekcjonerskich (Głosek 1984: 32-33, I42, nr kat. 63, 65). Dość dobrą analogię dla okazu ze Szczytna stanowi także miecz wybagrowany w 1967 r. między miejscowościami Piešt’any i Moravany z rzeki Váh (okr. Piešt’any). Jest on dość mocno zdekompletowany, jednak zachował się esowaty jelec oraz wąska głownia z odłamanym sztychem, ale zaopatrzona w dość krótkie zbrocze i znaki miecznicze wypełnione „żółtym” metalem. Wraz z mieczem pozyskano wówczas także esowaty jelec miecza. Zdeponowanie tych, jak i innych znalezionych w rzece zabytków uzbrojenia, jest łączone z działalnością militarną grup tzw. „bratrzyków” w latach 60. XV stulecia (Ruttkay 1989/1990: 93, 96, ryc. 2: 2, 3; Klčo, Krupa 2004: 39, 45 ryc. I:3 - tam dalsza literatura).

Omawiając zagadnienie mieczy z rękojeścią zaopatrzoną w esowate jelce, trzeba też wspomnieć o licznej grupie, w której głowniom w typach XX-XXII według R.E. Oakeshotta towarzyszą głowice w różnych wariantach typu z. Tego rodzaju miecze, z jelcami w stylu I2a-I2c, pochodzące przede wszystkim z terenów średniowiecznego Królestwa Węgier, są datowane przez M. Aleksića już od drugiej połowy XIV w. Jednak formy o silniej wygiętych ramionach jelca, czyli style I2b i I 2 , uznaje on generalnie za nieco młodsze, umieszczając je w przedziale czasowym od pierwszej połowy $\mathrm{XV}$ po schyłek tegoż stulecia. Charakterystyczne jest w tych przypadkach łączenie esowatych jelców z głowicami w różnych odmianach typu Z ( $z_{2}$ i Z3) oraz z szerokimi i krótkimi głowniami typu XX, w tym wydzielonego przez tegoż badacza nowego typu $x x b$, rzadziej innych wariantów (np. XıIIa, XVIa). Jest to dość powszechne zestawienie - ogółem M. Aleksić zebrał aż trzydzieści mieczy tego rodzaju pochodzących ze zbiorów południowo-wschodniej Europy oraz z kolekcji tureckich, przy czym te ostatnie mogły zostać zrabowane w Budzie przez Turków w 1526 r. Rejonem, w którym prowadzono produkcję mieczy o takich parametrach, mogły być tereny Serbii (Aleksić 2007: 97-103, 105-109, tabl. 17, map 8, I0, fig. 23, 31, Pl. 6:2, 7:I,4, I0:2, I7:I-4; por także Głosek 1984: 176, nr kat. $483-484,486-487)$. Na tym obszarze ich używanie jest poświadczone także przez źródła ikonograficzne w postaci przedstawień na nagrobkach (czy też tylko płytach nagrobnych) tzw. stećci. Na wielu z nich wyobrażono miecze wyposażone w esowate jelce oraz prostokątne czy gruszkowate głowice. Nagrobki tego rodzaju znane są z terenów Bośni i Hercegowiny, Chorwacji, Serbii oraz Czarnogóry. Mają one szerokie ramy chronologiczne: począwszy od XII po schyłek XV stulecia. Jednak rozpatrywane w tym miejscu wyobrażenia głowni z esowatymi jelcami pochodzą głównie z drugiej połowy XV w. (Aleksić 2007: Fig. 30, map 9; szerzej Florek 20I6: I46-I58, ryc. I, 3-6, 8-II, 2). Ustalenia M. Aleksića są zbieżne z wnioskami sformułowanymi wcześniej przez J. Kalmára, który dla terenu Królestwa Węgier ustalił, że miecze o dość masywnych, szerokich głowniach, łagodniej lub silniej 


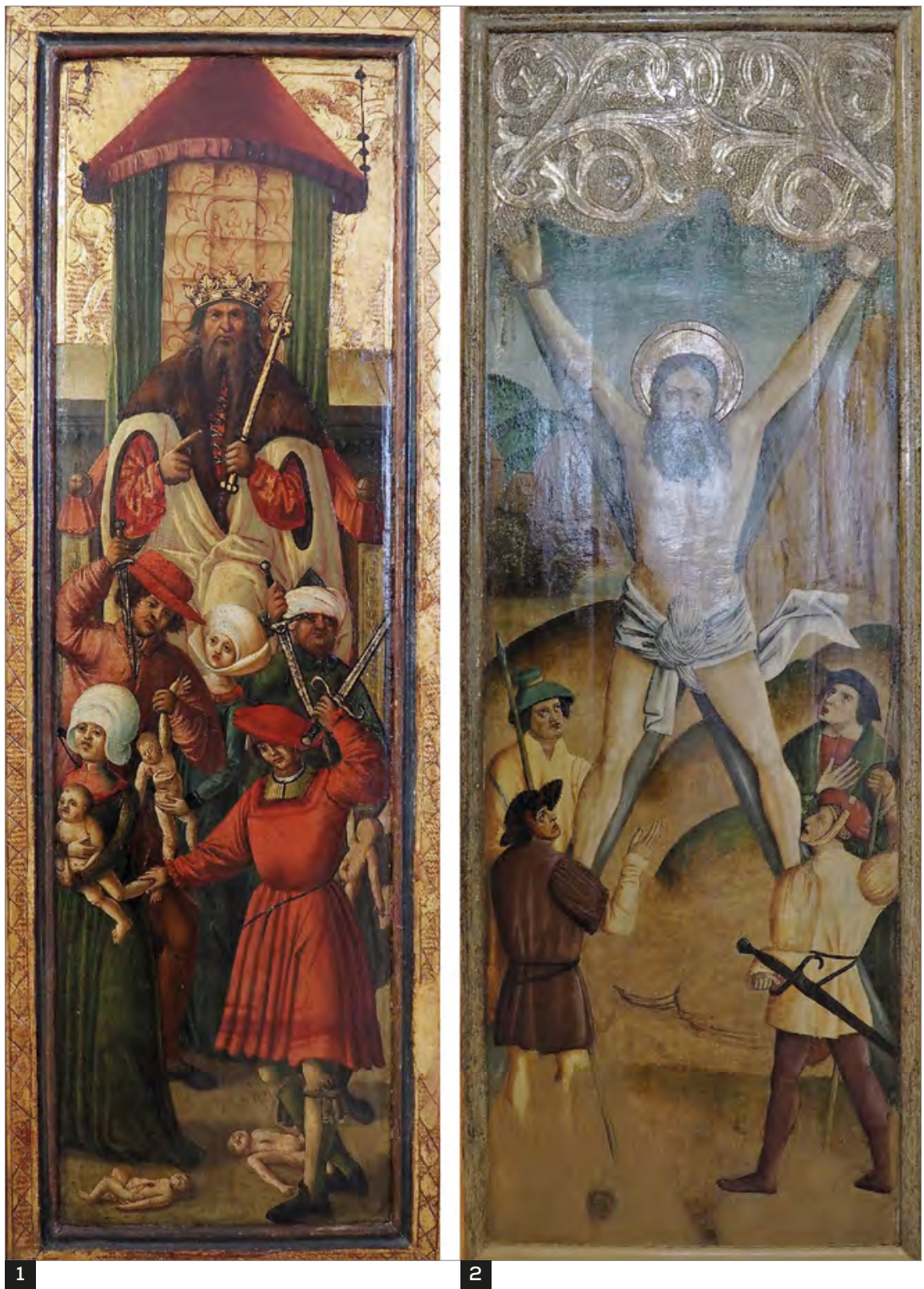

Ryc. 4. Miecze o wąskiej głowni i rękojeści z esowatym jelcem.

I - ołtarz św. Mikołaja, kościół pw. św. Franciszka z Asyżu w Hervartovie, okr. Bardejov, ok. I524 r.; 2 - skrzydło ołtarza z przedstawieniem św. Cyriaka, kościół pw. św. Andrzeja ze Zlatéj, okr. Bardejov, ok. I500-I520 r. Fot. P. Strzyż. 
wygiętych esowatych jelcach i kwadratowych głowicach pojawiły się w drugiej tercji XV stulecia za sprawą kontaktów z terenami północnej Italii oraz Wenecji (por. np. Carpegna di 1969: 36, nr kat. 204-205, 207). Co istotne, esowate jelce były stosowane także przy wczesnych szablach węgierskich (poł. XV w.), charakteryzujących się jeszcze symetryczną, mieczową rękojeścią (Kalmár 1971: 62, 71, ryc. IOI:f-h, I25; por. także Kovács 20I0: I22, I25, ryc. 63-64, 67-68).

Listę tego rodzaju przykładów uzupełnia np. egzemplarz, który jest przechowywany w Słoweńskim Muzeum Narodowym w Ljubljanie, a wyłowiony jeszcze w XIX w. z rzeki Ljubljanicy. Ma on dość długą i smukłą głownię w typie XX oraz rękojeść o esowatym jelcu i kwadratowej głowicy. Datowany jest na drugą połowę XV w. (Williams, Lazar 20I8: I24, Fig. 5:I-3). Inny, dobrze zachowany okaz jest przechowywany na zamku Červený Kameň (filii Słowackiego Muzeum Narodowego). Ma on głownię określoną jako typ xxiI z głowicą typu z. Datowany jest na drugą tercję XV w. (Čepela 2010: 77-79, ryc. 2: I-3, 4: 3-4, 5: I-2). Tego rodzaju miecze o głowni typu Xx lub XxI i esowatych jelcach znane są też np. ze zbiorów Museum für Deutsche Geschichte w Berlinie czy Muzeum Okręgowego w Toruniu. Czas ich powstania umieszcza się w drugiej połowie XV w. (Głosek I984: 153, I69, nr kat. 203, 394; Kwiatkowski 2016: 345, ryc. II.39:b; Majewski 2018: 50-5I, tab. I:16, Tabl. 5:5).

Miecze o esowatych jelcach i „gruszkowatych” głowicach są kategorią uzbrojenia, która ma liczną reprezentację ikonograficzną. Z terenu zakonu krzyżackiego w Prusach takim przykładem jest wyobrażenie miecza z pentaptyku z kościoła szpitalnego pw. Ducha Świętego w Bartoszycach (ryc. 3: I-2). W scenach Cierniem ukoronowanie oraz Ścięcie św. Barbary przedstawiono miecze typu XVIIIb wraz z jelcami stylu Iza lub I2b. Ołtarz ten jest datowany na lata około I5IO-I520 (Kwiatkowski 20I6: ryc. II.4O, II.4I). Ta forma broni białej jest obecna też w ikonografii Królestwa Polskiego. Są to np. przedstawienia z tryptyku z Więcławic (pierwotnie na Wawelu) z I 477 r., tryptyku z Połomii z około I 490 r. czy tryptyku z Dębna, datowanego na około I500 r. (Kajzer 1976: 134, ryc. 56, 61, 67). Z kolei z początku XVI stulecia (ok. I5ı2 r.) pochodzi wyobrażenie mieczy z poliptyku Mistrza Pasji Śląskiej z Archikatedry w Poznaniu (Marek 2008: 83, Fig. IIs:c). Podobnie są datowane przykłady wąskich głowni typu XVII-XVIII zaopatrzonych w esowate jelce z ołtarza św. Mikołaja z kościoła pw. św. Franciszka z Asyżu w Hervartovie, okr. Bardejov z około I52 4 r. autorstwa Teofila Stancela (ryc. 4: I) czy skrzydła ołtarza z przedstawieniem św. Cyriaka z kościoła pw. św. Andrzeja ze Zlatéj, okr. Bardejov, datowanego na około I500-I520 r. (ryc. 4: 2).

W przypadku miecza z zamku w Szczytnie brak jest, niestety, dokładniejszych danych odnośnie do okoliczności i miejsca odkrycia. Trudno ocenić, czy jego historia wiąże się ze średniowiecznymi dziejami zamku, miasta, czy zamek stał się jedynie miejscem przechowania oręża pochodzącego z innego miejsca na mapie 
zakonu. Pierwsze założenie obronne w Szczytnie (niem. Ortelsburg) powstało około I340-I359 r. jako drewniano-ziemna strażnica, ulokowana między jeziorami Długim i Małym. Wraz z sąsiadującymi założeniami w Ełku, Piszu, Szestnie, Barcianach, Giżycku i Węgorzewie miała osłaniać tereny zakonu od ataków z terenu Mazowsza i Litwy. W 1370 r. gród został zaatakowany i spalony przez litewskie oddziały księcia Kiejstuta. Na jego zgliszczach wkrótce rozpoczęto budowę zamku murowanego, który ukończono około I 400 r. Założenie, które miało stać się siedzibą prokuratora, zrealizowano jako regularny obiekt na planie kwadratu (bok dł. 39 m). Zabudowa objęła cztery skrzydła, które otaczały niewielki dziedziniec. W narożniku południowo-zachodnim ulokowano wysuniętą poza lico murów wieżę, która miała osłaniać wjazd bramny znajdujący się w skrzydle południowym. Obszerne przedzamcze chronił mur obwodowy, z dodanymi w późniejszym czasie (druga poł. XVI w.) narożnymi, cylindrycznymi bastejami (Haftka 1999: 298-30r; Kajzer i in. 200r: 477-479; Knyżewski 2020: I23-I24, 274, ryc. 6I). Jak się wydaje, zamek nie ucierpiał zbytnio w czasie toczących się na terenie Prus wojen z Królestwem Polski i Wielkim Księstwem Litewskim (I409-I4II, I454-I 466 oraz I519-I52I); trudno zatem sądzić, iż to wówczas doszło do zdeponowania miecza (por. np. Haftka 1999: 299-300; Biskup 20I4: 167). Niestety, zachowane inwentarze zamkowe tylko wybiórczo informują nas o przechowywanych w Szczytnie zasobach uzbrojenia - wymieniają kusze, broń palną i uzbrojenie ochronne, nie wspominają natomiast o broni białej, która zapewne jako ekwipunek osobisty nie podlegała wyszczególnieniu (por. Das Grosse... I921: II5-I23; Haftka 1999: 299-300).

Mając na uwadze przytoczone informacje, możemy stwierdzić, że miecz z całą pewnością nie jest starszy niż przełom XIV/XV w. Jego cechy konstrukcyjne, szczególnie zaś esowaty jelec i gruszkowata głowica, pozwalają określić czas jego powstania zapewne w okolicach połowy $\mathrm{XV}$ w. Jednak jak długo mógł on pozostawać w użyciu nie sposób ocenić. Przedstawione analogie poświadczają, że miecze o wąskich głowniach w typach XVII, XVIIIa, XVIIIb i zaopatrzonych w esowate jelce i gruszkowate głowice były szczególnie chętnie stosowane przez całą drugą połowę XV i początek następnego wieku. Z kolei wyobrażenia mieczy o takich cechach w ikonografii, zarówno tej z terenu zakonu czy Królestwa Polskiego, pozwalają zauważyć, że mogły być z powodzeniem w obiegu co najmniej do schyłku pierwszej ćwierci XVI stulecia, a nawet nieco dłużej. Wobec braku dokładniejszych danych, tak też należy datować zabytek z zamku w Szczytnie. 


\section{Bibliografia}

\section{Źródła}

Das Grosse Ämterbuch des Deutschen Ordens, red. E.Ziesemer, Danzig I92I.

\section{Opracowania}

Adamiak M., Zdaniewicz R. (2015), Żelazna szabla ze zbiorów Muzeum w Gliwicach, „Acta Militaria Mediaevalia”, I5, s. 215-224.

Aleksić M. (2007), Mediaeval Swords from Southeastern Europe. Material from $\mathrm{I}^{\text {th }}$ to I5 ${ }^{\text {th }}$ Century, Dedra, Belgrade.

Augustyniak J. (1988), Gantelet - fragment d'armure datant du XVI siècle et provenent du château d'Inowtódz, dép. de Piotrków (Pologne Centrale), „Fasciculi Archaeologiae Historicae", 2, s. 7-9.

Augustyniak J. (1992), Zamek w Inowtodzu, Muzeum Archeologiczne i Etnograficzne, Łódź (Biblioteka Muzeum Archeologicznego i Etnograficznego w Łodzi, 26).

Augustyniak J. (1996), Splendory izby magnackiej $w$ XVI wieku na przyktadzie zamku w Inowtodzu, „Archeologia Historia Polona”, 3, s. 209-223.

Biborski M., Stepiński J., Żabiński G. (2004), A Renaissance Sword from Racibórz, "Gladius", 24, s. 187-208, https://doi.org/10.3989/gladius.2004.4I

Biskup M. (2014), „Wojna pruska” czyli wojna Polski z Zakonem krzyżackim z lat I5I9-I52I. U źródet sekularyzacji Prus krzyżackich, Napoleon v, Oświęcim.

Bruhn Hoffmeyer A. (1954), Middelalderens tveeggede svard I-II, Tøjhusmuseet, København.

Carpegna di N. (1969), Antiche armi dal. sec. IX al XVIII giá Collezione Odescalchi, De Luca Editore, Roma.

Čepela V.(2010), Tri stredoveké chladnézbrane v zbierkach SNM-Múzea Červený Kameñ, „Vojenská história. Časopis pre vojenské históriu, múzejníctvo a archívnictvo”, I4.3, s. $75-87$.

Florek M. (2016), Broń na średniowiecznych nagrobkach tzw. „stećci” z Batkanów. Wstęp do problematyki, „Acta Militaria Mediaevalia”, I2, s. 135-174.

Głosek M. (1973), Znaki i napisy na mieczach średniowiecznych $w$ Polsce, Zakład Narodowy im. Ossolińskich, Wrocław-Warszawa-Kraków-Gdańsk.

Głosek M. (1984), Miecze środkowoeuropejskie $z X-X V w$., Wydawnictwa Geologiczne, Warszawa.

Głosek M. (1990), Broń biata dtuga, [w:] A. Nadolski (red.), Uzbrojenie w Polsce średniowiecznej 1350-I450, Polska Akademia Nauk. Instytut Historii Kultury Materialnej, Łódź, S. III-I24.

Głosek M. (1998), Broń biata, [w:] A. Nowakowski (red.), Uzbrojenie w Polsce średniowiecznej 1450-I50o, Uniwersytet Mikołaja Kopernika w Toruniu, Toruń, s. 23-40. 
Głosek M., Kajzer L., Nadolski A. (1978), Broń średniowieczna z ziem polskich. Katalog. Polska Akademia Nauk, Łódź.

Grygiel R., Jurek T. (1996), Doliwowie z Nowego Miasta nad Warta, Dębna i Biechowa. Dzieje rezydencji i ich wtaścicieli, Muzeum Archeologiczne i Etnograficzne w Łodzi, Łódź.

Haftka M. (1999), Zamki krzyżackie w Polsce. Szkice z dziejów, Wydawnictwo consorT; Muzeum Zamkowe w Malborku, Malbork-Płock.

Hošek J., Košta J., Žakovský P. (2019), Ninth to Mid-sixteenth Century Swords from the Czech Republic in their European Context, part I, The Finds, The Czech Academy of Sciences. Institute of Archaeology, Prague-Brno.

Kajzer L. (1976), Uzbrojenie i ubiór rycerski w średniowiecznej Matopolsce w świetle źródet ikonograficznych, Zakład Narodowy im. Ossolińskich, Wrocław-Warszawa-KrakówGdańsk.

Kajzer L., Kołodziejski S., Salm J. (200I), Leksykon zamków w Polsce, Arkady, Warszawa.

Kalmár J. (1971), Régi magyar fegyverek, Natura, Budapest.

Klčo M., Krupa V.(2004), Stredoveké zbrane v zbierkach Balneologického muzea $v$ Pieśt’anoch, [w:] K. Malečková (red.), Zbrane a zbroj. Zbornik príspevkov zo sympózia usporiadaného prí priležitosti výstavy Zbrane a zbroj, sNM - Múzeum Bojnice, Bojnice, s. 37-52.

Knyżewski M. (2020), Siedziby średnich i niższych ranga urzędników krzyżackich na terenie dzisiejszej Polski. Studium archeologiczne, Instytut Archeologii Uniwersytetu Łódzkiego, Łódź (Monografie Instytutu Archeologii Uniwersytetu Łódzkiego, II).

Kovács T.S. (2010), Huszárfegyverek a I5-17. században, Martin Opitz Kiadó, Budapest.

Kozłowski R. (1978), Badanie i konserwacja przedmiotów z grobu Kazimierza Jagiellończyka, „Studia do Dziejów Wawelu”, 4, s. 460-476.

Krajíc R., Kukla Z., Nekuda V.(1997), Středověký meč ze Mstěnic, [w:] R. Nekuda, J. Unger (red.), Z pravěku do středověku. Sbornik k 7o. narozeninam Vladimira Nekudy, Muzejní a vlastivědená společnost v Brně, Moravské zemské muzeum, Brno, s. 250-258.

Kwiatkowski K.(2016), Wojska zakonu niemieckiego w Prusach I230-I525. Korporacja, jej pruskie wtadztwo, zbrojni, kultura wojny i aktywność militarna, Uniwersytet Mikołaja Kopernika w Toruniu, Toruń.

Ławrynowicz O.(2005), Treści ideowe broni rycerskiej w Polsce w wiekach średnich, Łódzkie Towarzystwo Naukowe, Łódź (Acta Archaeologica Lodziensia, 5I).

Majewski M.(20I8), Uzbrojenie średniowieczne w ziemi chełmińskiej (mps pracy doktorskiej przygotowanej w Instytucie Archeologii Uniwersytetu Mikołaja Kopernika w Toruniu, w zbiorach autora).

Marek L. (2004), Wczesnośredniowieczne miecze z Europy Środkowej i Wschodniej. Dylematy archeologa i bronioznawcy, Wydawnictwo Uniwersytetu Wrocławskiego, Wrocław (Studia Archeologiczne, 26).

Marek L. (2008), Broń biata na Śląsku XIV-XVI wiek, Wydawnictwo Uniwersytetu Wrocławskiego, Wrocław (Wratislavia Antiqua, Io).

Marek L. (20I4), Europejski styl. Militaria z Elblaga i okolic, Wydawnictwo Uniwersytetu Wrocławskiego, Wrocław (Studia Archeologiczne, 47). 
Marek L. (2017), Średniowieczne uzbrojenie Europy tacińskiej jako Ars Emblematica, Wydawnictwo Uniwersytetu Wrocławskiego, Wrocław (Wratislavia Antiqua, 22).

Nadolski A. (1984), Polska broń - broń biata, Zakład Narodowy im. Ossolińskich, Wrocław-Warszawa-Kraków-Gdańsk.

Norman A.V.B. (1980), The Rapier and Small-Sword: 1460-1820, Arms and Armour Press; Arno press, London-New York.

Oakeshott R.E. (1997), The Sword in the Age of Chivalry, Boydell Press, Woodbridge.

Pudło P. (2010), ...By w Polsce znaleźć swe miejsce ('średniowiecze i nowożytność), [w:] S. Cegłowski, K. Demkowicz, R. Janiak, T.Kordala, P. Łuczak, P. Pudło, Skarby z ziemi wydobyte, Muzeum Diecezjalne w Płocku, Płock, s. 47-52, 92-106.

Ruttkay A.(1989/1990), Militáriá a súcasti jezdeckého výstroja z I5. stor. na Kostolci $v$ Moravanoch nad Váhom, miestna čast'Ducové, „Sborník Prací Filozofické Fakulty Brněnské University", 38/39, řada archeologicko-klasicka, 34-35, s. 89-ı I.

Wilkus K. (1991), Odkrycie grobów królewskich w katedrze wileńskiej, „Studia do Dziejów Wawelu", 5, s.530-550.

Williams A., Lazar T. (2018), A Group of Medieval Swords from the National Museum of Slovenia - Metallographic Analyses and Hardness Testing, „Acta Militaria Mediaevalia", I3, S. II5-I29.

Żabiński G., Biborski M., Stępiński J. (2014), Technology of Sword Blades from the La Tène Period to the Early Modern Age. The Case of what is now Poland, Archaeopress, Oxford, https://doi.org/I0.2307/j.ctvqmpi4Z

Žakovský P. (20II), Středověké a ranè novověké chladné zbraně ze sbirek Mèstkého muzea $v$ Moravském Krumlovè, [w:] Z. Měrinsky (red.), Hrad jako technicky problem. Technologie a formy vystavby středověkych opevnènych sidel, Brno (Archeologia mediaevalis Moravica et Silesiana, 2), s. I27-188.

\section{Summary}

The article discusses the sword stored in the Mazuria Museum in Szczytno (inv. no. MMA-30/920/72). It comes from the pre-war collection of the Prussia Museum and has not been published before. The item is preserved in fairly good condition - only the stock part of the head is missing. The sword head is quite narrow and preserved at a length of $615 \mathrm{~mm}$, with a total length of the weapon $855 \mathrm{~mm}$. The cross-guard is very distinctive, with an $S$-shaped top projection, and it was made of an iron bar with a variable polygonal cross-section. The pommel has the form of an inverted pear and is slightly damaged at the base.

On the basis of its constructional features, the sword from Szczytno should be classified as a late medieval specimen with a type Xvinia blade according to R.E. Oakeshott, I2a cross-guard and Ts pommel. Analogous surviving specimens from contemporary Poland and Central Europe, as well as iconographic representations prove that this type of sword, with slender, rhomboidal blade, $S$-shaped cross-guard and pear-shaped pommel, was most popular in the second half of the $\mathrm{I}^{\text {th }}$ century and the first quarter of the $16^{\text {th }}$ century. As the information about the circumstances of obtaining this piece is 
too laconic - it was supposed to have been found at the castle - we can only generally date it as the above quoted examples.

Keywords: sword, Szczytno, Castel, Middle Ages, Teutonic Order

\author{
Piotr Strzyż \\ Uniwersytet Łódzki \\ Wydział Filozoficzno-Historyczny \\ Instytut Archeologii \\ e-mail: piotr.strzyz@uni.lodz.pl
}

